Sains Malaysiana 50(3)(2021): 559-570

http://dx.doi.org/10.17576/jsm-2021-5003-01

\title{
Jatropha curcas L. and Pongamia pinnata L. Exhibited Differential Growth and Bioaccumulation Pattern Irrigated with Wastewater
}

(Jatropha curcas L. dan Pongamia pinnata L. Mempamerkan Pertumbuhan Pembezaan dan Corak Bioakumulasi yang Diairkan dengan Air Buangan)

Rafia Abid*, Seema Mahmood, Saman Zahra, Shazia Ghaffar, Mahwish Malik \& Sibgha Noreen

\section{ABSTRACT}

Pakistan currently faces an acute shortage of water, which has increasingly been devastating for the past few decades. In order to mitigate water scarcity, agriculture sector of the country started using wastewater discharged from various industries. The present study aims to assess the impact of fertilizer industry effluent on Jatropha curcas $L$. and Pongamia pinnata L., which are popular biofuel tree species. Initially, one-year-old saplings were acclimatized in pots, then wastewater was applied in diluted concentrations of effluent using 20 and $40 \mathrm{~mL} \mathrm{~L}^{-1}$ to the treatment group while control

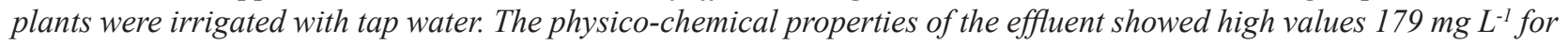

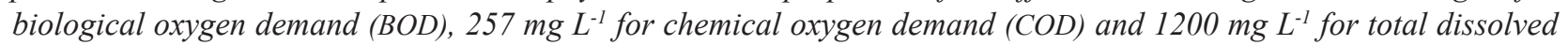
solid (TDS), respectively. Surprisingly, high concentrations of arsenic $\left(15 \mu \mathrm{g} \mathrm{L^{-1 }}\right)$ and cadmium $\left(0.78 \mathrm{mg} \mathrm{L}^{-1}\right)$ were present but chromium $(\mathrm{Cr})$ concentration was found within permissible limit to WHO. The levels applied caused a significant $(p \leq 0.05)$ increase in plant growth and biomass. The extent of membrane damage assessed via malondialdehyde (MDA) production was also greater in the roots of $\mathrm{P}$. pinnata while reverse was true for shoots of $\mathrm{J}$. curcas. A more profound $(p \leq 0.05)$ reduction in photosynthetic pigments and carotenoids was observed in P. pinnata at concentrated level of effluent. Overall, the study signifies a 2-folds potential of biofuel tree species for efficient reuse of wastewater, as well as for remediation of metals from wastewater and soil.

Keywords: Heavy metals; Jatropha curcas; lipid peroxidation; photosynthetic pigments; Pongamia pinnata

\section{ABSTRAK}

Pakistan baru-baru ini menghadapi kekurangan air yang teruk dan ia semakin teruk sejak beberapa dekad yang lalu. Bagi mengatasi kekurangan air, sektor pertanian di negara ini mula menggunakan air buangan yang dikeluarkan daripada pelbagai industri. Kajian ini bertujuan untuk menilai kesan efluen industri baja pada Jatropha curcas L. dan Pongamia pinnata L. yang merupakan spesies pokok bahan api biologi yang terkenal. Pada mulanya, anak pokok berusia satu tahun diaklimat dalam pasu, kemudian air sisa limbah digunakan dalam kepekatan efluen yang cair dengan menggunakan 20 dan $40 \mathrm{~mL} \mathrm{~L}^{-1}$ pada kelompok rawatan manakala tanaman kawalan diairi dengan air paip. Sifat fisiko-kimia efluen menunjukkan nilai yang tinggi masing-masing sebanyak $179 \mathrm{mg} \mathrm{L}^{-1}$ untuk permintaan oksigen biologi (BOD), $257 \mathrm{mg}$ $L^{-1}$ untuk permintaan oksigen kimia (COD) dan $1200 \mathrm{mg} \mathrm{L}^{-1}$ untuk jumlah pepejal terlarut (TDS). Anehnya, kepekatan arsenik (15 $\left.\mu \mathrm{g} \mathrm{L}^{-1}\right)$ dan kadmium (0,78 $\left.\mathrm{mg} \mathrm{L}^{-1}\right)$ yang tinggi hadir tetapi kepekatan kromium (Cr) dijumpai dalam had yang dibenarkan kepada WHO. Tahap yang digunakan menyebabkan peningkatan ( $\leq \leq 0.05)$ pertumbuhan tanaman dan biojisim yang ketara. Tahap kerosakan membran yang dinilai melalui pengeluaran malondialdehid (MDA) juga lebih besar pada akar P. pinnata manakala sebaliknya berlaku untuk pucuk J. curcas. Pengurangan pigmen fotosintesis dan karotenoid yang lebih mendalam $(p \leq 0.05)$ diperhatikan pada P. pinnata pada tahap efluen yang pekat. Secara keseluruhan, kajian ini menunjukkan potensi spesies pokok bahan api biologi sebanyak 2 kali ganda untuk penggunaan semula air buangan yang berkesan, serta untuk pemulihan logam dari air buangan dan tanah.

Kata kunci: Jatropha curcas; logam berat; peroksidasi lipid; pigmen fotosintesis; Pongamia pinnata

\section{INTRODUCTION}

Water is the most valuable resource on planet earth. Like many other densely populated countries of the world, Pakistan is also facing the challenge of water scarcity for crop production. Pakistan has been declared as the most water scarce countries of the world (Arif et al. 2018). In order to combat acute water shortage and high cost of fertilizers, the cooperative farmers have started to use 
industrial wastewater for crop production. In addition, the use of chemical fertilizers becomes necessary owing to deficiency of various essential nutrients in the soils of the country. Most arable soils are mostly calcareous and are deficient in macronutrients such as nitrogen $(\mathrm{N})$, phosphorus $(\mathrm{P})$ and potassium $(\mathrm{K})$ as well as micronutrients such as boron (B) and zinc (Zn) (Rehim et al. 2016). Nutrient balance in soil is maintained by integrated nutrient approaches such as crop rotation, green manuring, microbes/biofilterlizers but preference has always been given to the use of chemical fertilizers owing to subsidized cost, particularly in the absence of any kind of tax both for industry and consumer (Iqbal et al. 2015).

The global market for chemical fertilizers is expected to be 151.8 billion USD and major investments for their production have been done in Pakistan. Despite substantial earnings by this sector, all production units are major contributors of various types of contaminants that are thrown into the environment without following EPA standards (Abid et al. 2019; Manzoor et al. 2015). Almost all industrial effluents are heavily loaded with several contaminants having high biological oxygen demand (BOD), chemical oxygen demand (COD), total dissolved solid (TDS), total suspended solid (TSS) and heavy metals (Younas et al. 2017) like arsenic (As), cadmium (Cd), and chromium $(\mathrm{Cr})$ which are of serious concern (Ronzan et al. 2017). The PAK-EPA surveys reported more alarming figures for As in ground water and found 12-488 $\left(\mu \mathrm{g} \mathrm{L}^{-1}\right)$ As concentration in drinking water in Tehsil Mailsi, Punjab. These amounts are far greater than the permissible limit (10 $\mu \mathrm{g} \mathrm{L}^{-1}$ ) by WHO (Rasool et al. 2017). Afzal et al. (2014) reported enhanced concentrations of $\mathrm{Cd}\left(37 \mathrm{mg} \mathrm{kg}^{-1}\right)$ and $\mathrm{Cr}\left(2443 \mathrm{mg} \mathrm{kg}^{-1}\right)$ in soils of Kasur, Punjab, Pakistan where industrial wastewater was used for irrigation.

The As, $\mathrm{Cd}$, and $\mathrm{Cr}$ are toxic metals of co-existence in nature (Ronzan et al. 2017). As is ranked at 1st, Cd at 7 th and hexavalent $\mathrm{Cr}$ (VI) at 17 th positions among the hazardous pollutants by ATSDR (2017). The As, Cd and $\mathrm{Cr}$ VI are carcinogenic and neurotoxic, and cause respiratory depression in humans (ATSDR 2017). The major dilemma associated with heavy metals is their persistence, non-biodegradability and bioaccumulation in plants (Chang et al. 2014) causing considerable decline in crop productivity leading to food security issues (Shahid et al. 2017) and risk to humans though food chain contamination (Zare et al. 2018).

Mitigation of soil contamination involves some expensive techniques such as chemical amendment, physical, and mechanical methods. However, in the last two decades, low cost and environmentally friendly techniques for removal of heavy metals from ecosystem called phytoremediation/bioremidation have received considerable attention (Dadea et al. 2017). Using woody plants/species such as Ailanthus altissima, Betula pendula,
Robinia pseudoacacia on contaminated soil showed great prospective for phytoremediation due to their high growth rate, high transpiration rate, deep root systems, high biomass and capacity to accumulate metals in their shoots (Constán-Nava et al. 2010; Dadea et al. 2017). Though metal tolerance has been reported from a wide range of wild and cultivated plant species including trees, shrubs and herbs that have potential to extract metal from soil (Luo et al. 2016) but these reports clearly demonstrate that herbaceous cultivated species have greater sensitivity for toxic levels of metals than woody shrubs and trees (Wang et al. 2016). Nevertheless, for both tolerance and sensitivity, the underlying physiological and biochemical mechanisms govern the ultimate expression of the plants. This involves inhibition of chloroplast biosynthesis, disturbance of electron transport chain, photosynthesis, water uptake, oxidation of amino acids, damage to biological membranes and DNA and RNA via oxidative stress (Ronzan et al. 2017).

Although extensive work has been carried out to explore the potential of trees regarding $\mathrm{As}, \mathrm{Cd}$ and $\mathrm{Cr}$ contamination through tolerance mechanism (Dadea et al. 2017; Hussain et al. 2017), but a little effort has been done so far to discover the responses of long-lived biofuel species such as Jatropha curcas and Pongamia pinnata. Keeping in view the growing concerns on As, $\mathrm{Cd}$, and $\mathrm{Cr}$ and the exploitation of some biofuel species for remediation purposes, the aim of the present study was to assess the growth and biochemical responses of the two biofuel yielding species and the pattern of metal accumulation in their tissues in addition to changes in physico-chemical properties of soil after the application of effluent from a fertilizer factory containing substantial amount of $\mathrm{As}, \mathrm{Cd}$, and $\mathrm{Cr}$, and then to evaluate their phytoremediation potential.

\section{MATERIALS AND METHODS}

\section{SAMPLE COLLECTION AND EXPERIMENTAL DESIGN}

The effluent (35 L) was collected from Pakarab Fertilizer (Pvt.) Ltd., Multan, Punjab, Pakistan during peak working hours of the factory. The effluents were drained into main Kacha canal through water courses and drainage system without any pretreatment. Prior to the growth experiment, the effluent was analyzed for physico-chemical parameters such as $\mathrm{pH}$, temperature, electrical conductivity (EC), biological oxygen demand (BOD), chemical oxygen demand (COD), total dissolved solid (TDS), dissolved oxygen (DO), total suspended solid (TSS) and sulphates following the standard protocols by American Public Health Association (APHA 2012). Total As, Cd, and $\mathrm{Cr}$ concentration in the effluent was determined with Atomic Absorption Spectrometer (AAS) Agilent 200 Series, AA 
System California, USA. In March 2016, one-year-old uniform saplings of $J$. curcas and P. pinnata obtained from a local nursery were transplanted into plastic pots $(\mathrm{h} \times \mathrm{d}$ : $25 \times 22 \mathrm{~cm}$ ) filled with $6 \mathrm{~kg}$ of a sandy loam soil.

The experiment with three replicates for each treatment was placed in a Complete Randomized Design (CRD) in a wire netting greenhouse with $28 \pm 2{ }^{\circ} \mathrm{C}, 12 \mathrm{~h}$ day time, and $38 \%$ relative humidity. The effluent dilutions (20 and $40 \mathrm{mLL}^{-1}$ ) were applied as treatments, control pots were irrigated with tap water. After acclimatization of plants for 8 weeks, each pot/plant was irrigated with $2 \mathrm{~L}$ for each treatment after regular interval of 3 months from June 2016 to June 2017. Effluent was applied three times in year. Water loss was compensated by gentle sprinkling of tap water when required.

After 12 months exposure of effluent, the plants were harvested and soil samples were collected from rhizospheric zone. Physico-chemical analysis of soil ( $\mathrm{pH}, \mathrm{EC}$, total nitrogen \%, available potassium, available phosphorus and soil texture) was carried out using laboratory manual (US Salinity Laboratory Staff 1954). Wet double acid digestion for soil and plants was carried out with $4: 1 \mathrm{HNO}_{3}: \mathrm{HClO}_{4}(\mathrm{v} / \mathrm{v})$ following Allen et al. (1986) at $100{ }^{\circ} \mathrm{C}$ by using Microwave Digestion System (MDS 2000, Canada). Total As, Cd, and Cr contents in soil and plant tissues were determined with Atomic Absorptions Spectrometer (Agilent 200 Series, AA System California, USA). The minimum detection limit was $0.01,0.0001$ and $0.1 \mathrm{ppm}$ for $\mathrm{As}, \mathrm{Cd}$, and $\mathrm{Cr}$, respectively, and the recovery rate was $98 \%$ for $\mathrm{As}, 96 \%$ for $\mathrm{Cd}$ and $101 \%$ for $\mathrm{Cr}$. The range of detection limit was 0.01-2 ppm for As, 0.0001-10 ppm for Cd and 0.01-100 ppm for Cr. The accuracy of the analytical method was confirmed by the determination of the content by AA standards for As, Cd and Cr (Camlab, U.K.) to estimate their total amounts in plant tissues. The AsIII concentration was determined by the use of arsenic speciation cartridge (Waters SPE cartridge) for wastewater samples and AsV concentration was calculated by subtracting AsIII from total As following Mathews et al. (2010) through SPE cartridge for speciation of AsV and AsIII.

\section{MORPHOLOGICAL AND BIOCHEMICAL PARAMETERS}

Plant growth attributes such as root and shoot elongation, dry biomass of root and shoot, leaf area, number of leaves per plant and collar diameter were measured after the application of effluent. The standard protocols were used for each parameter for consistent measurements (Abid et al. 2019). Photosynthetic pigments (chlorophyll a, b and total) and total carotenoids $(\mathrm{Cx}+\mathrm{c})$ were determined as described by Lichtenthaler (1987).
ESTIMATION OF LIPID PEROXIDATION LEVELS IN PLANT TISSUES

The concentration of MDA in root and shoot was measured by following de Oliveira et al. (2014) with minor modifications. The MDA concentration was calculated as the difference in absorbance at 600 and 532 $\mathrm{nm}$ using extinction coefficient of $156 \mathrm{mmol}^{-1} \mathrm{~cm}^{-1}$.

\section{STATISTICAL ANALYSIS}

Data presented as means of three replicates $( \pm$ S.E) for each parameter was subjected to Two Way Analysis of Variance (ANOVA) to elucidate the effect of effluent (12 month treatment) on the growth of species. Mean values were compared separately by using a post-hoc Tukey's HSD test. The level of significance for all parameters was set at $\mathrm{p} \leq 0.05$ using statistical software (SAS Version 13.1 Inc., Cary, NC, USA).

\section{RESULTS AND DISCUSSION}

After 12 months of exposure with 20 and $40 \mathrm{~mL} \mathrm{~L}^{-1}$ of effluent, morpho-biochemical parameters, MDA concentration, As, $\mathrm{Cd}$, and $\mathrm{Cr}$ concentration were measured in $J$. curcas and $P$. pinnata relative to their respective control plants. Physico-chemical properties of the effluent and its impact on soil characteristics were also assessed.

\section{PHYSICO-CHEMICAL PROPERTIES OF EFFLUENT}

Analysis of physico-chemical properties of effluent revealed light yellowish colour and high temperature of the effluent (Table 1). The concentrations of EC, BOD, COD, TDS, TSS, total As, Cd, P, and $\mathrm{N}$ were higher than permissible limit by World Health Organization (WHO) for irrigation water (Table 1). However, DO, chloride (Cl), potassium $(\mathrm{K})$, sodium $(\mathrm{Na})$ and sulphate $\left(\mathrm{SO}_{4}^{2-}\right)$ were found to be below while $\mathrm{pH}$, arsenite (AsIII), arsenate $(\mathrm{AsV})$, and chromium (Cr) were within safe limit of WHO. The cumulative results for BOD, COD, TDS, TSS, total $\mathrm{As}$, and $\mathrm{Cd}$ served as major pollution indicators to depict strength of effluent as per quality profile of wastewater (APHA 2012). These predictors represented both biodegradable and non-biodegradable oxidizable pollutants in the wastewater discharge from the factory.

Chemical characterization of the effluent from various industrial units have been carried out by other workers (Arif et al. 2016; Biswas et al. 2018; Roohi et al. 2016). Their reports conferred consistent results for quality parameters of wastewaters. The characterization of the colour is an important parameter because the strength of coloration strongly suggests impurities present 
in wastewater and its treatment for reuse. The yellowish colour of effluent has been reported to contain more dissolved salts and other substances. Our findings are in parallel to Afzal et al. (2014) and Imtiazuddin et al. (2014) describing strong coloration of wastewater from tannery and textile industries. The industrial wastewater discharged with high temperature than permissible limit set by WHO can be a potential cause for thermal pollution of water bodies that can led to increase BOD and decrease DO by the aquatic organism for oxygen. Our result on temperature is parallel to the findings of Patel et al. (2015) who reported similar increase in temperature of effluent discharged from other textile units. The higher EC alters the chelating properties of wastewater system, which create conditions for free metal availability to flora and fauna (Younas et al. 2017). More AsV contents had been detected than AsIII. Shakoor et al. (2015) found more AsV concentration and attributed it to continuous pumping of groundwater that oxidize metal elements present in subsurface sediment and aquifers. In our study, As pollution levels in the effluents exhibited a similar pattern as that of groundwater that is more concentration of $\mathrm{AsV}$ than AsIII, since the source of water used by industrial process is groundwater. The data regarding As speciation in wastewater has not been reported so far, but Brahman et al. (2014) and Shakoor et al. (2015) carried out As speciation in the groundwater of Punjab and Sindh Provinces of Pakistan. Our results are in parallel to Shakoor et al. (2015) for more AsV contents than AsIII. However, our findings are contrary to Brahman et al. (2014) who reported more concentration of AsIII than AsV in groundwater in District Tharparker, Sindh. Thus, parallel existence of both forms of As (III and V) in groundwater as well as in effluent discharged from fertilizer factory can be established from this study. However, $\mathrm{N}$ and $P$ in the fertilizer effluent found can be beneficial for plant growth as reported by Kumar et al. (2017b). But on the other hand, more $\mathrm{N}$ and $\mathrm{P}$ have been described to produce nitrophos (Younas et al. 2017). Thus, dilution of effluent reduced its toxicity level.

TABLE 1. Physical-chemical properties of effluent collected from Fertilizer Factory, Multan, Pakistan

\begin{tabular}{|c|c|c|}
\hline Water parameters & Values & Permissible limit (WHO) \\
\hline \multicolumn{3}{|c|}{ Physico-chemical analysis } \\
\hline Color & Light yellowish & Colorless \\
\hline $\mathrm{pH}$ & 7.6 & 6.5 to 8.5 \\
\hline Temperature $\left({ }^{\circ} \mathrm{C}\right)$ & 30 & $<30{ }^{\circ} \mathrm{C}$ \\
\hline $\mathrm{EC}(\mathrm{mS} / \mathrm{cm})$ & 1.324 & 0.4 \\
\hline $\mathrm{BOD}\left(\mathrm{mg} \mathrm{L}^{-1}\right)$ & 179 & 80 \\
\hline $\operatorname{COD}\left(\mathrm{mg} \mathrm{L}^{-1}\right)$ & 257 & 10 \\
\hline $\mathrm{DO}\left(\mathrm{mg} \mathrm{L}^{-1}\right)$ & 2.6 & $4-7$ \\
\hline $\operatorname{TDS}\left(\mathrm{mg} \mathrm{L}^{-1}\right)$ & 1200 & 1000 \\
\hline $\operatorname{TSS}\left(\mathrm{mg} \mathrm{L}^{-1}\right)$ & 274 & 150 \\
\hline $\mathrm{Cl}^{-}$ & 14 & 250 \\
\hline $\mathrm{K}^{+}\left(\mathrm{mg} \mathrm{L}^{-1}\right)$ & 5.5 & 12 \\
\hline $\mathrm{Na}^{+}\left(\mathrm{mg} \mathrm{L}^{-1}\right)$ & 129 & 200 \\
\hline Total N $\left(\mathrm{mg} \mathrm{L}^{-1}\right)$ & 59 & 2.5 \\
\hline Total $\mathrm{P}\left(\mathrm{mg} \mathrm{L}^{-1}\right)$ & 0.97 & 0.05 \\
\hline $\mathrm{SO}_{4}^{2-}\left(\mathrm{mg} \mathrm{L}^{-1}\right)$ & 240 & 500 \\
\hline \multicolumn{3}{|c|}{ Metals } \\
\hline Total As $\left(\mu \mathrm{g} \mathrm{L}^{-1}\right)$ & 15 & $10\left(\mu \mathrm{g} \mathrm{L}^{-1}\right)$ \\
\hline AsIII $\left(\mu \mathrm{g} \mathrm{L}^{-1}\right)$ & 5 & $10\left(\mu \mathrm{g} \mathrm{L}^{-1}\right)$ \\
\hline $\operatorname{AsV}\left(\mu \mathrm{g} \mathrm{L}^{-1}\right)$ & 10 & $10\left(\mu \mathrm{g} \mathrm{L}^{-1}\right)$ \\
\hline $\mathrm{Cd}\left(\mathrm{mg} \mathrm{L}^{-1}\right)$ & 0.78 & 0.003 \\
\hline $\mathrm{Cr}\left(\mathrm{mg} \mathrm{L}^{-1}\right)$ & 0.04 & 0.05 \\
\hline $\mathrm{Hg}\left(\mathrm{mg} \mathrm{L}^{-1}\right)$ & $\mathrm{BDL}$ & \\
\hline $\mathrm{Pb}\left(\mathrm{mg} \mathrm{L}^{-1}\right)$ & BDL & \\
\hline
\end{tabular}

EC (Electrical Conductivity), BOD (Biological oxygen demand), COD (Chemical oxygen demand, TDS (Total dissolved solids), DO (Dissolved oxygen) and TSS (Total suspended solid) and WHO (World Health Organization) 
PHYSICAL-CHEMICAL PROPERTIES OF SOIL AFTER FERTILIZER EFFLUENT APPLICATION

The changes in soil properties after the application of effluent provided were observed (Table 2). The $\mathrm{pH}$ of soil was found to be alkaline ranging at 8.4-9.4. The high $\mathrm{pH}$ of soil after effluent treatment is an indication of more accumulation of cations such as $\mathrm{P}, \mathrm{Ca}$, and $\mathrm{Mg}$ that changed the $\mathrm{pH}$. Our findings are similar to that of Hossain et al. (2015) who found changes in soil $\mathrm{pH}$ after irrigation with industrial effluent. More alkaline $\mathrm{pH}$ of the soil can be attributed to various salts present in the effluent. A significant increase in soil EC, 16-93\% for $J$. curcas, was noticed at 20 and $40 \mathrm{~mL} \mathrm{~L}^{-1}$ of effluent, respectively. For $P$. pinnata $82-183 \%$ increase in soil EC was observed at respective levels of effluent. Increase in soil EC signifies increase in soil salinity. Higher soil salinity is an indication of more ions present in the effluent that contributed increase in soil EC. The increase in soil EC may also be attributed to $\mathrm{pH}$ modification and nutrients availability in soil after the length of exposure (Table 2). Our results are in lines with Ahmad et al. (2012) who reported more increase in soil EC treated with industrial effluent. Irrigation with wastewater having high $\mathrm{pH}$ and EC could potentially increase soil exchangeable complexes and alkaline hydrolysis reactions (Chaerun et al. 2011). All such changes also alter soil structure and can affect the soil microflora.

In addition to soil $\mathrm{pH}$ and $\mathrm{EC}$, soil organic matter $(\mathrm{OM})$ is an indicative of soil fertility and appeared to be of particular interest for study carried out for heavy metals sorption in soil as it affects the mobility of heavy metals by forming insoluble and soluble organic complexes (Alamgir 2016). At elevated level of effluent, OM content increased $138-182 \%$ in soil samples collected from $P$. pinnata and $J$. curcas as compared to their respective controls. An increase in soil OM might be due to long term application of effluent that resulted decay in plant parts and nematode decay that served as the source of carbon. Our findings are comparable to Mobar et al. (2015) who reported more OM in soil when source of irrigation was textile effluent. Maurya (2017) also observed similar increase in soil OM content in sandy loam soil with alkaline $\mathrm{pH}$. OM improves water retention capacity of sandy and sandy loamy soil and also provide suitable conditions to enhance soil microflora. The soil used for this study was also sandy loam with alkaline $\mathrm{pH}$ thus exhibited the above properties. Further, sandy soil poses lesser restriction and is ease for root penetration that results in extensive development of underground tissue system while loamy soil is advantageous because of their higher nutrient retention properties, owing to more clay particles which possess negative charges and bind macronutrients with positive charge. This binding increases the fertility of the soil, thus it is considered as the best medium for plant growth. Issa et al. (2009) also provided similar arguments for varied types of soil textures. Our results depicted that available $\mathrm{P}, \mathrm{K}$, and total $\mathrm{N}(\%)$ increased in soil when irrigated with 20 and $40 \mathrm{~mL} \mathrm{~L}^{-1}$ effluent as compared to control plant soil samples. However, a maximum increase $(10.1 \%)$ in $\mathrm{N}$ at $40 \mathrm{~mL} \mathrm{~L}^{-1}$ effluent level and available $\mathrm{K}$ and $\mathrm{P}\left(\mathrm{K} ; 260\right.$ and $\left.\mathrm{P} ; 2.73 \mathrm{mg} \mathrm{kg}^{-1}\right)$ at $20 \mathrm{~mL} \mathrm{~L}^{-1}$ effluent level. The observed change in available amount of $\mathrm{P}$ and $\mathrm{K}$ and total $\mathrm{N}$ contents in soil corresponded with higher levels of $\mathrm{K}, \mathrm{N}$ and $\mathrm{P}$ in the industrial effluent is in close conformity with Arif et al. (2016) and Rani et al. (2017) who reported more $\mathrm{K}, \mathrm{N}$ and $\mathrm{P}$ contents in soil irrigated with different dilutions of industrial effluent. Furthermore, these studies documented that increase in soil $\mathrm{pH}$ and $\mathrm{EC}$ promotes the more concentrations of $\mathrm{K}, \mathrm{P}$ and $\mathrm{N}$, and these findings are consistent with the results of this study and more $\mathrm{pH}$ and EC values after the application of fertilizer wastewater.

TABLE 2. Changes in soil properties and metal concentrations (As, $\mathrm{Cd}$ and $\mathrm{Cr}$ ) under varying levels of effluent from a fertilizer factory

\begin{tabular}{|c|c|c|c|c|c|c|}
\hline \multirow{2}{*}{ Soil parameters } & \multicolumn{3}{|c|}{ J. curcas } & \multicolumn{3}{|c|}{ P. pinnata } \\
\hline & T0 & $\mathrm{T} 1$ & $\mathrm{~T} 2$ & T0 & $\mathrm{T} 1$ & $\mathrm{~T} 2$ \\
\hline $\mathrm{pH}$ & $7.5 \pm 0.09^{\mathrm{a}}$ & $8.90 \pm 0.09^{b}$ & $9.20 \pm 0.07^{\mathrm{c}}$ & $7.00 \pm 0.06^{\mathrm{a}}$ & $8.40 \pm 0.06^{\mathrm{a}}$ & $9.4 \pm 0.12^{b}$ \\
\hline $\mathrm{EC}(\mathrm{mS} / \mathrm{cm})$ & $2.70 \pm 0.04^{\mathrm{a}}$ & $3.13 \pm 0.08^{b}$ & $5.21 \pm 0.07^{\mathrm{c}}$ & $1.73 \pm 0.01^{\mathrm{a}}$ & $3.14 \pm 0.03^{b}$ & $4.90 \pm 0.1^{\mathrm{c}}$ \\
\hline Organic matter (\%) & $0.66 \pm 0.03^{\mathrm{a}}$ & $1.39 \pm 0.06^{\mathrm{b}}$ & $1.86 \pm 0.09^{\mathrm{ab}}$ & $0.96 \pm 0.02^{\mathrm{a}}$ & $1.09 \pm 0.02^{\mathrm{b}}$ & $2.28 \pm 0.02^{\mathrm{c}}$ \\
\hline Total N (\%) & $0.29 \pm 0.0^{\mathrm{a}}$ & $9.70 \pm 0.02^{\mathrm{b}}$ & $8.90 \pm 0.01^{\mathrm{c}}$ & $0.94 \pm 0.03^{\mathrm{a}}$ & $9.60 \pm 0.02^{\mathrm{b}}$ & $10.1 \pm 0.03^{\mathrm{b}}$ \\
\hline Available $\mathrm{K}\left(\mathrm{mg} \mathrm{kg}^{-1}\right)$ & $100 \pm 4.04^{\mathrm{a}}$ & $260 \pm 7.2^{\mathrm{b}}$ & $140 \pm 6.00^{c}$ & $120 \pm 3.02^{\mathrm{a}}$ & $120 \pm 5.57^{\mathrm{a}}$ & $140 \pm 5.57 .7^{\mathrm{b}}$ \\
\hline Available P $\left(\mathrm{mg} \mathrm{kg}^{-1}\right)$ & $0.26 \pm 0.01^{\mathrm{a}}$ & $2.73 \pm 0.09^{b}$ & $0.14 \pm 0.02^{\mathrm{c}}$ & $0.96 \pm 0.02^{\mathrm{a}}$ & $0.16 \pm 0.02^{\mathrm{b}}$ & $0.20 \pm 0.02^{\mathrm{b}}$ \\
\hline As $\left(m g \mathrm{~kg}^{-1}\right)$ & $1.20 \pm 0.01^{\mathrm{a}}$ & $13.90 \pm 0.01^{\mathrm{b}}$ & $13.80 \pm 0.01^{\mathrm{b}}$ & $14.40 \pm 0.01^{\mathrm{a}}$ & $13.80 \pm 0.01^{\mathrm{b}}$ & $13.60 \pm 0.01^{\mathrm{b}}$ \\
\hline $\mathrm{Cd}\left(\mathrm{mg} \mathrm{kg}^{-1}\right)$ & $0.66 \pm 0.01^{\mathrm{a}}$ & $1.25 \pm 0.01^{\mathrm{b}}$ & $0.85 \pm 0.01^{\mathrm{ac}}$ & $0.94 \pm 0.01^{\mathrm{a}}$ & $0.81 \pm 0.01^{\mathrm{a}}$ & $1.03 \pm 0.02^{\mathrm{b}}$ \\
\hline $\mathrm{Cr}\left(\mathrm{mg} \mathrm{kg}^{-1}\right)$ & $0.88 \pm 0.01^{\mathrm{a}}$ & $0.92 \pm 0.02^{\mathrm{b}}$ & $0.84 \pm 0.01^{\mathrm{a}}$ & $0.63 \pm 0.01^{\mathrm{a}}$ & $0.72 \pm 0.02^{\mathrm{b}}$ & $0.79 \pm 0.01^{b}$ \\
\hline
\end{tabular}

Control (T0), $20 \mathrm{~mL} \mathrm{~L}^{-1}$ (T1) and $40 \mathrm{ml} \mathrm{L}^{-1}(\mathrm{~T} 2)$. Values are expressed as mean $\pm \mathrm{S}$.E with $\mathrm{n}=3$. Different letters at the top of each column depict significant variation between effluent levels at $\mathrm{p} \leq 0.05$ using Turkey's HSD test 
The concentrations of As (13.80 $\left.\mathrm{mg} \mathrm{kg}^{-1}\right), \mathrm{Cd}(1.25$ $\left.\mathrm{mg} \mathrm{kg}{ }^{-1}\right)$ and $\mathrm{Cr}\left(0.92 \mathrm{mg} \mathrm{kg}^{-1}\right)$ were found greater in soil samples of $J$. curcas at more diluted level as compared to control plant soil samples. While $P$. pinnata had higher concentration for $\mathrm{Cd}\left(1.03 \mathrm{mg} \mathrm{kg}^{-1}\right)$ and $\mathrm{Cr}\left(0.79 \mathrm{mg} \mathrm{kg}^{-1}\right)$ after the application of less diluted level than control soil samples (Table 2). Higher concentrations of metals in the soil might be due to irrigation of soil with wastewater. Furthermore, these metals are naturally occurred in soil and are non-biodegradable and remain persistent in the soil. Parallel findings reported by Rekik et al. (2017) who found more concentrations of $\mathrm{As}, \mathrm{Cd}$ and $\mathrm{Cr}$ in soil after the long term application of industrial effluents.

\section{MORPHOLOGICAL AND BIOCHEMICAL PARAMETERS IN$$
J \text {. curcas AND P. pinnata }
$$

After the application of effluent, changes were observed for morpho-biochemical expressions of $J$. curcas and $P$. pinnata. Both species exhibited a significant $(\mathrm{p} \leq 0.05)$ increase in root length, shoot length, collar diameter, root and shoot biomass, number of leaves, and leaf area at 20 $\mathrm{mL} \mathrm{L}^{-1}$ (Figure 1). Root length was more pronounced in $J$. curcas which showed $70 \%$ increase then $21 \%$ enhancement in $P$. pinnata. J. curcas exhibited $17 \%$ reduction in root length when treated with $40 \mathrm{~mL} \mathrm{~L}^{-1}$ affluent (Figure 1(a) and $1(\mathrm{~b})$ ). However, shoot elongation increased $30 \%$ and $36 \%$ in J. curcas and P. pinnata, respectively. While shoot dry biomass increased $58 \%$ in J. curcas and only $22 \%$ elongation in root dry biomass for more diluted level than their respective control (Figure $1(\mathrm{~g})$ and $1(\mathrm{~h})$ ). Both species also sustained growth at an elevated level $\left(40 \mathrm{~mL} \mathrm{~L}^{-1}\right)$ of effluent but only $J$. curcas showed significant increase for dry root biomass extent and root collar diameter relative to the control plants (Figure 1(c) and 1(h)). Number of leaves per plant increased 2-3 folds in both species at less diluted level $\left(40 \mathrm{~mL} \mathrm{~L}^{-1}\right)$ relative to their respective control (Figure 1(f)). At $40 \mathrm{~mL} \mathrm{~L}^{-1}$, leaf surface also expanded 32 and $33 \%$ in J. curcas and P. pinnata in comparison to their control plant counterparts (Figure 1(e)).

Enhanced growth, dry biomass production and greater leaf area indicate the sustainable growth of the species under effluent application that contains many essential macro and micronutrients, including NPK (Table 1; Figure $1(\mathrm{~g})$ and $1(\mathrm{~h})$ ). Nitrogen being important component of proteins, cellular material, DNA and RNA might have contributed towards growth and biomass enhancement of the species. Thus, as such many principal nutrients have resulted positive impact on health and vigor of the plant particularly for foliage attributes (Kumar et al. 2017b). Similarly, P and K have a beneficial influence because of the pivotal role for many metabolic activities of plants. The positive impact of NPK was also well documented for $J$. curcas and P. pinnata where application of fertilizers caused greater biomass production of the species (Kumar et al. 2017b; Manzoor et al. 2015).

Although no significant reduction in chlorophyll b was found in J. curcas at more diluted level of the effluent, however a higher concentration of effluent caused a profound reduction in chlorophyll $\mathrm{a}, \mathrm{b}$, and total in addition to carotenoids in both species (Figure 2). The presence of ions including heavy metals in the effluent might have substituted $\mathrm{Mg}^{2+}$ ions in the chlorophyll molecules. Metal ions are able to decrease the activity of - $\mathrm{SH}$ group of enzymes that result in formation of heavy metal complexes with chlorophyll, thus decreased biosynthesis of chlorophyll and other pigments. An early senescence of leaves with chlorosis induced by metal stress is well documented for decline in photosynthetic pigments (Rekik et al. 2017; Shah et al. 2010). Nevertheless, the robust nature plastids and their structural modifications as orientation and self-replicating properties make them more resistant to environmental stresses including heavy metal.

Effluent impacted the TBARS concentration in roots and shoots of the species than their respective controls. TBARS production in terms of maliondialdyhyde (MDA) is used as measure of oxidative stress through ROS generation and is dependent on the extent of stress. An increase in MDA by 4 and 2.5 folds in roots, and 3 and 7 folds in shoots of $J$. curcas and P. pinnata were recorded at $40 \mathrm{~mL} \mathrm{~L}^{-1}$ effluent than control plants that signified generation of ROS (Abid et al. 2019). The increase in MDA concentrations indicates that plants can tolerate stress caused by effluent and heavy metals due to the activation of enzymatic and non-enzymatic anti oxidative defense systems of plants which cater for oxidative stress in the plants (Kandziora-Ciupa et al. 2016).

\section{METAL ACCUMULATION POTENTIAL OF $J$. curcas AND $P$. pinnata}

The concentrations of $\mathrm{As}, \mathrm{Cd}$, and $\mathrm{Cr}$ were determined in plant parts after the application of effluent in varying dilutions (Table 3). The ability of plants to translocate metals from below ground tissues to aerial parts is due to translocation factor (Baker 1981). A consistent pattern of arsenic (As) accumulation was recorded in both species, and it was significantly $(p \leq 0.05)$ higher in the shoot (Table 4). However, J. curcas showed greater As concentration $\left(8.48 \mathrm{mg} \mathrm{kg}^{-1}\right)$ as compared to $P$. pinnata $\left(8.18 \mathrm{mg} \mathrm{kg}^{-1}\right)$ in shoots at elevated level of 

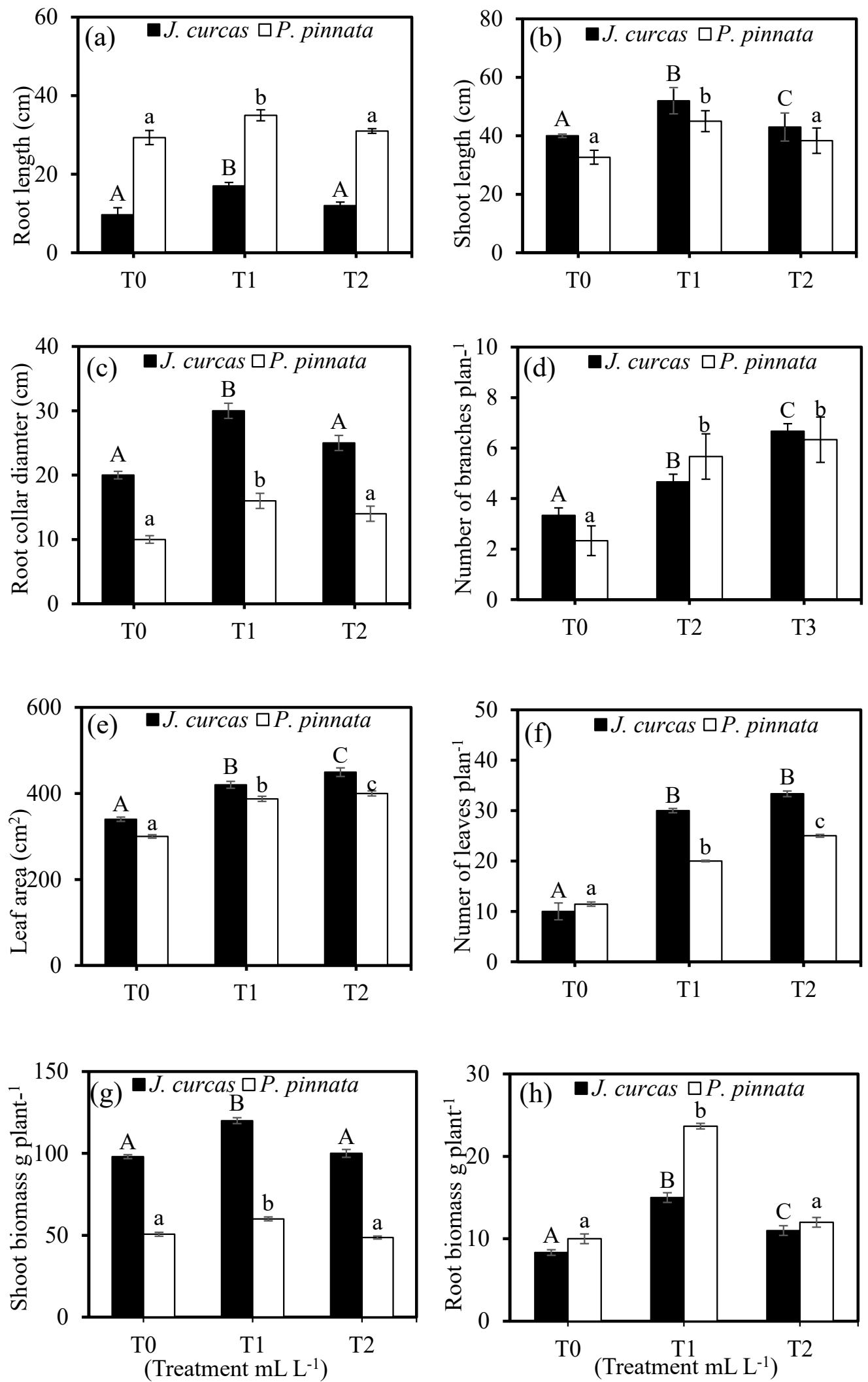

FIGURE 1. Morphological parameters of $J$. curcas and P. pinnata, irrigated with effluent levels; control (T0), $20 \mathrm{~mL} \mathrm{~L}^{-1}$ (T1) and $40 \mathrm{~mL} \mathrm{~L}^{-1}$ (T2). Data presents mean \pm S.E. dw=dry weight. Mean comparisons for each plant species were done separately and indicated by uppercase and lower case letters. Different letters at the top of each column depict significant variation between effluent levels at $\mathrm{p} \leq 0.05$ using Turkey's HSD test 

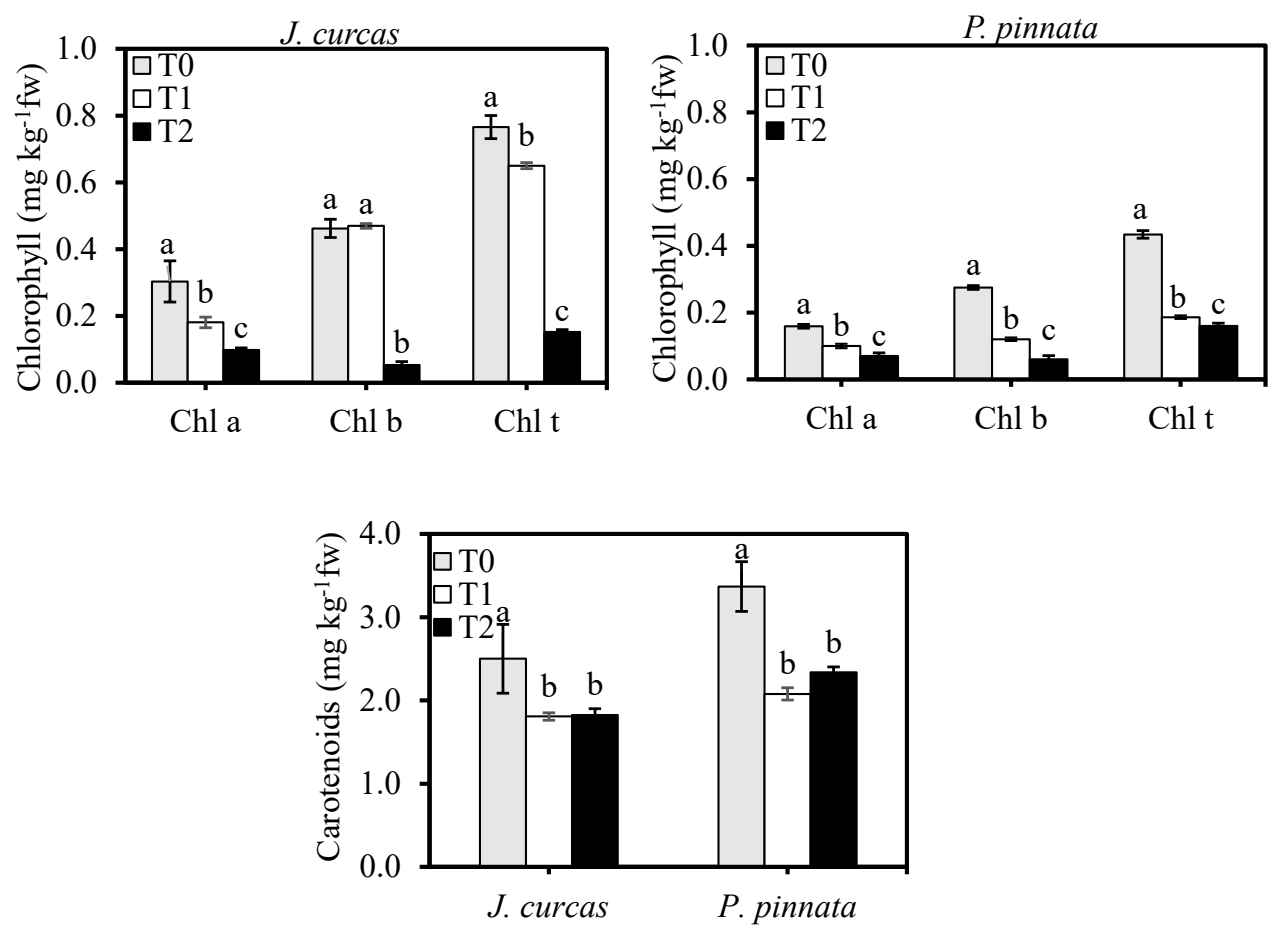

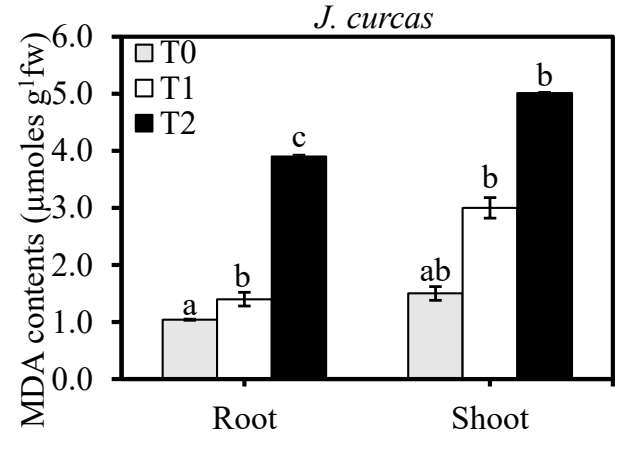

(Treatment $\mathrm{mL} \mathrm{L}^{-1}$ )

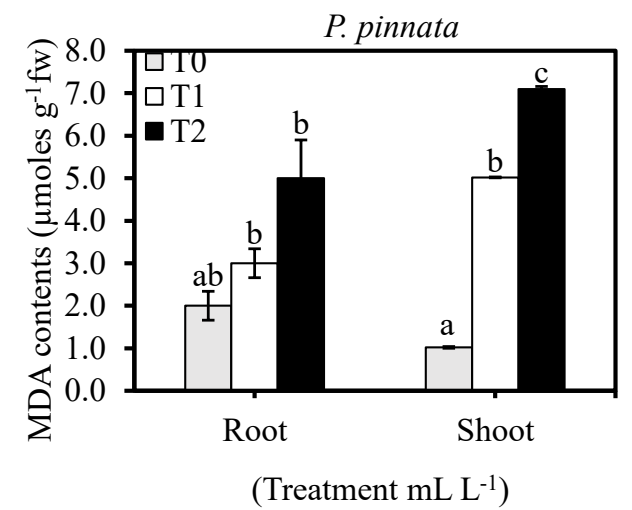

FIGURE 2. Biochemical parameters of $J$. curcas and P. pinnata, irrigated with effluent levels; control (T0), 20 $\mathrm{mL} \mathrm{L}^{-1}(\mathrm{~T} 1)$ and $40 \mathrm{~mL} \mathrm{~L}^{-1}(\mathrm{~T} 2)$. Data presents mean \pm standard error, fw $=$ fresh weight. Different letters at the top of each column depict significant variation between effluent levels at $p \leq 0.05$ using Turkey's HSD test

effluent. A similar trend was also observed in roots where accumulation of As was greater $\left(6.10 \mathrm{mg} \mathrm{kg}^{-1}\right)$ in roots of $J$. curcas than P. pinnata $\left(4.20 \mathrm{mg} \mathrm{kg}^{-1}\right)$ at the effluent level. On the basis of translocation factor, P. pinnata showed more potential for As translocation from root to shoot (Table 4). Our findings are parallel to Kumar et al. (2017a) who reported much greater accumulation of As in the above ground parts ( $\left.3663 \mathrm{mg} \mathrm{kg}^{-1}\right)$ than roots $\left(3233 \mathrm{mg} \mathrm{kg}^{-1}\right)$ in $P$. pinnata and regarded it as As accumulator species. Study regarding As uptake and accumulation in $J$. curcas is not available, but Pteris vittata as an As hyperaccumulator is well reported. Though fern has different vascular anatomy, the translocation pattern of more As in shoots $(4973 \mathrm{mg}$ $\mathrm{kg}^{-1}$ ) than roots $\left(698 \mathrm{mg} \mathrm{kg}^{-1}\right)$ were reported (Lessl et al. 2015). However, their findings should be compared with great cautions. Nevertheless, the greater quantity of metal in above ground parts of both the species can be ascribed to phosphate transporter. In another fern study, more As was 
found to be transported to aboveground tissues via xylem loading, thus significant quantity of metals was found in the shoots (de Oliveira et al. 2018).

Translocation of $\mathrm{Cd}$ to the shoots was higher for $J$. curcas $\left(7.07 \mathrm{mg} \mathrm{kg}^{-1}\right)$ than $P$. pinnata $\left(2.72 \mathrm{mg} \mathrm{kg}^{-1}\right)$ at elevated level of fertilizer wastewater (Tables $3 \&$ 4). Our findings are in parallel to Nan et al. (2013) who found higher $\mathrm{Cd}$ concentration in aboveground part (14 $\mathrm{mg} \mathrm{kg}^{-1}$ ) than roots $\left(4 \mathrm{mg} \mathrm{kg}^{-1}\right)$ of Polygonum hydropiper when irrigated with river water receiving effluents of various industries. Nevertheless, greater amount of $\mathrm{Cd}$ in aboveground part have also been reported in other plants (Ahmad et al. 2015; Huang et al. 2011; Ismail et al. 2014).

Jatropha curcas and $P$. pinnata had contrasting behaviors for $\mathrm{Cr}$ translocation when irrigated with both levels of fertilizer effluent (Table 4). J. curcas exhibited a marked contrast to $\mathrm{Cr}$ that remained substantially higher (39\%) in the shoots whereas $P$. pinnata showed more deposition of $\mathrm{Cr}(23 \%)$ in roots than shoots at less diluted level of effluent. The accumulation of $\mathrm{Cr}$ in $J$. curcas and $P$. pinnata again signified a differential capacity of the tissues of the two species to accumulate $\mathrm{Cr}$. These findings are in parallel to Malik et al. (2010) who reported more $\mathrm{Cr}$ translocation from roots $\left(18.5 \mathrm{mg} \mathrm{kg}^{-1}\right)$ to shoots $(49.7 \mathrm{mg}$ $\mathrm{kg}^{-1}$ ) in Malvestrum coromandialinum grown in various zones receiving industrial wastewaters. Our findings are also in parallel to Bernabé-Antonio et al. (2015) who reported more $\mathrm{Cr}$ translocation from roots to shoots in $\mathrm{J}$. curcas. However, more $\mathrm{Cr}$ in the roots of $P$. pinnata can be ascribed to its immobilization in underground tissues (de Oliveira et al. 2016).

The pattern of As, $\mathrm{Cd}$, and $\mathrm{Cr}$ translocation in $J$. curcas followed a similar trend for metal accumulation and translocation into aboveground tissues thereby suggesting the phytoextraction potential of the species. It is highly likely that the species acquired an active mechanism for the translocation of these metals for their transport. Presumably, sulphate, phosphate, and iron might serve as common transporters for As and $\mathrm{Cr}$ (de Oliveira et al. 2018), but, Zn/Fe regulator-like protein (ZIP) played a role for translocation for $\mathrm{Cd}$ (Zare et al. 2018). In addition, the variability of the state of the metal also profoundly influence either accumulation in roots or further translocation to shoots. $P$. pinnata appeared to be a metal tolerant species through phytostabilization for $\mathrm{Cr}$ and metal extractor for As and $\mathrm{Cd}$. Both the species are non-edible and potential biofuel trees and have differential metal accumulation strategy, thus they can be a choice for $\mathrm{As}, \mathrm{Cd}$, and $\mathrm{Cr}$ contaminated soils or in situation where irrigation water contain these metals. Conclusively, both the species have potential for phytoremediation which is either acquired through phytostabilization or phytoextraction, and thus serve as valuable future biofuel energy plants.

TABLE 3. Metal concentration in J. curcas and P. pinnata in plant tissue under varying levels of effluent from a fertilizer factory

\begin{tabular}{|c|c|c|c|c|c|c|}
\hline \multirow{3}{*}{$\begin{array}{l}\text { Treatment } \\
\left(\mathrm{mL} \mathrm{L}^{-1}\right)\end{array}$} & \multicolumn{6}{|c|}{ Metal concentrations $\left(\mathrm{mg} \mathrm{kg}^{-1} \mathrm{dw}\right)$} \\
\hline & \multicolumn{2}{|c|}{ As } & \multicolumn{2}{|c|}{$\mathrm{Cd}$} & \multicolumn{2}{|c|}{$\mathrm{Cr}$} \\
\hline & Root & Shoot & Root & Shoot & Root & Shoot \\
\hline \multicolumn{7}{|c|}{ J. curcas } \\
\hline T0 & $3.00 \pm 0.21^{\mathrm{a}}$ & $3.41 \pm 0.04^{\mathrm{a}}$ & $1.0 \pm 0.01^{\mathrm{a}}$ & $2.35 \pm 0.02^{\mathrm{a}}$ & $1.16 \pm 0.04^{\mathrm{a}}$ & $1.00 \pm 0.01^{\mathrm{a}}$ \\
\hline $\mathrm{T} 1$ & $4.92 \pm 0.2^{\mathrm{b}}$ & $8.90 \pm 0.02^{\mathrm{b}}$ & $3.03 \pm 0.31^{\mathrm{b}}$ & $5.96 \pm 0.00^{\mathrm{b}}$ & $1.32 \pm 0.01^{\mathrm{b}}$ & $1.85 \pm 0.03^{\mathrm{b}}$ \\
\hline $\mathrm{T} 2$ & $6.10 \pm 0.06^{\mathrm{c}}$ & $8.48 \pm 0.01^{\mathrm{c}}$ & $4.81 \pm 0.04^{\mathrm{c}}$ & $7.07 \pm 0.01^{\mathrm{c}}$ & $1.22 \pm 0.01^{\mathrm{b}}$ & $1.69 \pm 0.01^{\mathrm{c}}$ \\
\hline \multicolumn{7}{|c|}{ P. pinnata } \\
\hline T0 & $3.13 \pm 0.19^{\mathrm{a}}$ & $3.22 \pm 0.1^{\mathrm{a}}$ & $1.02 \pm 0.04^{\mathrm{a}}$ & $1.89 \pm 0.01^{\mathrm{a}}$ & $1.0 \pm 0.021^{\mathrm{a}}$ & $0.87 \pm 0.04^{\mathrm{a}}$ \\
\hline $\mathrm{T} 1$ & $4.60 \pm 0.24^{\mathrm{b}}$ & $8.60 \pm 0.02^{\mathrm{b}}$ & $1.36 \pm 0.02^{\mathrm{b}}$ & $2.30 \pm 0.01^{\mathrm{b}}$ & $1.42 \pm 0.01^{\mathrm{a}}$ & $1.27 \pm 0.03^{\mathrm{b}}$ \\
\hline $\mathrm{T} 2$ & $4.20 \pm 0.21^{\mathrm{b}}$ & $8.18 \pm 0.03^{c}$ & $2.47 \pm 0.03^{c}$ & $2.77 \pm 0.09^{c}$ & $2.20 \pm 0.33^{\mathrm{b}}$ & $1.70 \pm 0.02^{\mathrm{c}}$ \\
\hline
\end{tabular}

Control (T0), $20 \mathrm{~mL} \mathrm{~L}^{-1}$ (T1) and $40 \mathrm{~mL} \mathrm{~L}^{-1}$ (T2). Values are expressed as mean \pm S.E with $\mathrm{n}=3$. DW=Fresh weight. Different letters at the top of each column depict significant variation between effluent levels at $\mathrm{p} \leq 0.05$ using Turkey's HSD test 
TABLE 4. Translocation factor (TF) of As, Cd, and $\mathrm{Cr}$ in J. curcas and P. pinnata under varying levels of effluent from a fertilizer factory

\begin{tabular}{|c|c|c|c|}
\hline Treatment $\left(\mathrm{mL} \mathrm{L}^{-1}\right)$ & As & $\mathrm{Cd}$ & $\mathrm{Cr}$ \\
\hline & $\mathrm{TF}$ & $\mathrm{TF}$ & $\mathrm{TF}$ \\
\hline \multicolumn{4}{|c|}{ J. curcas } \\
\hline T0 & 1.13 & 2.35 & 0.86 \\
\hline $\mathrm{T} 1$ & 1.80 & 1.96 & 1.40 \\
\hline $\mathrm{T} 2$ & 1.39 & 1.46 & 1.38 \\
\hline \multicolumn{4}{|c|}{ P. pinnata } \\
\hline T0 & 1.02 & 1.85 & 0.87 \\
\hline $\mathrm{T} 1$ & 1.86 & 1.69 & 0.89 \\
\hline $\mathrm{T} 2$ & 1.94 & 1.12 & 0.77 \\
\hline
\end{tabular}

Translocation factor; Ratio of shoot and root metal concentrations. Translocation factor of metal excluder species is $\mathrm{TF}<1$ whereas metal accumulator species has TF $>1$ (Baker 1981)

\section{CONCLUSION}

Positive impact of the effluent was observed in J. curcas and $P$. pinnata for the growth parameters studied. However, some adverse effect of effluent was noticed on chlorophyll and carotenoid at higher doses. Nevertheless, the innate tolerance for the heavy metals and potential of species for growth make them a successful candidate for phytoremediation through phytoextraction or phytostabilization. These biofuel species can be grown by using heavily contaminated industrial effluents to save irrigation water and its cost that resolve the water scarcity problem. Both the species can be a choice for phytoremediation programs as well as a source of ecofriendly fuel for future.

\section{ACKNOWLEDGEMENTS}

The data presented in this manuscript is a part of Ph.D. research of the first author. Authors gratefully acknowledge agriculture officer Mr. Mohammad Khalid Rasheed, Soil and Water Testing Laboratory for Research for providing laboratory facilities.

\section{REFERENCES}

Abid, R., Mahmood, S., Ghaffar, S., Zahra, S. \& Noreen, S. 2019. Tannery effluent induced morpho-biochemical expressions and chromium accumulation in Jatropha curcas L. and Pongamia pinnata L. Sains Malaysiana 48(5): 927-936.

Afzal, M., Shabir, G., Iqbal, S., Mustafa, T., Khan, Q.M. \& Khalid, Z.M. 2014. Assessment of heavy metal contamination in soil and groundwater at leather industrial area of Kasur, Pakistan. Clean-Soil, Air, Water 41(9999): 1-7.
Ahmad, M.T., Sushil, M. \& Krishna, M. 2012. Influence of dye industrial effluent on physico chemical characteristics properties of soil at Bhairavgarh, Ujjain, MP, India. Research Journal of Environment Sciences 1(1): 50-53.

Ahmad, R., Liaqat, S., Noor, E., Qayyum, A., Irshad, A., Hussain, A., Ahmed, G., Karim, A. \& Mahmood, S. 2015. A multivariate analysis approach for evaluating diverse germplasm of cotton (Gossypium hirsutum L.) for seed and fibre characteristics. Basic Research Journal of Agricultural Science and Review 4: 164-171.

Alamgir, M. 2016. The effects of soil properties to the extent of soil contamination with metals. In Environmental Remediation Technologies for Metal-Contaminated Soils, edited by Hasegawa, H., Rahman, I.M.M. \& Rahman, M.A. Tokyo: Springer. pp. 11-19.

American Public Health Association (APHA). 2012. Standard Methods for the Examination of Water and Wastewater. 22nd ed. Washington DC: American Public Health Association. pp. 1-22.

Arif, M.S., Riaz, M., Shahzad, S.M., Yasmeen, T., Ashraf, M., Siddique, M., Mubarik, M.S., Bragazza, L. \& Buttler, A. 2018. Fresh and composted industrial sludge restore soil functions in surface soil of degraded agricultural land. Science of The Total Environment 619-620: 517-527.

Arif, M.S., Riaz, M., Shahzad, S.M., Yasmeen, T., Buttler, A., Garcia-Gil, J.C., Roohi, M. \& Rasool, A. 2016. Contrasting effects of untreated textile wastewater onto the soil available nitrogen-phosphorus and enzymatic activities in aridisol. Environmental Monitoring and Assessment 188(102): 1-15.

Allen, S., Grimshaw, H. \& Rowland, A. 1986. Chemical analysis. In Methods in Plant Ecology, edited by Moore, P.D. \& Chapman, S.B. London: Oxford. pp. 411-466.

Agency for Toxic Substances and Disease Registry (ATSDR). 2017. Website; Priority List of Hazardous Substances. US 
Department of Health and Human Services. http://www.atsdr. cdc.gov/SPL/index.html.

Baker, A.J.M. 1981. Accumulators and excluders strategies in the response of plants to heavy metals. Journal of Plant Nutrition 3(1-2): 643-654.

Bernabé-Antonio, A., Álvarez, L., Buendía-González, L., Maldonado-Magaña, A. \& Cruz-Sosa, F. 2015. Accumulation and tolerance of $\mathrm{Cr}$ and $\mathrm{Pb}$ using a cell suspension culture system of Jatropha curcas. Plant Cell, Tissue and Organ Culture 120(1): 221-228.

Biswas, S., Bhattacharya, A. \& Basak, P. 2018. Effect of tannery effluent on germination and early seedling growth of Oryza sativa var. IET-4786. In Utilization and Management of Bioresources, edited by Gosh, S.K. Singapore: Springer. pp. 243-251.

Brahman, K.D., Kazi, T.G., Baig, J.A., Afridi, H.I., Khan, A., Arain, S.S. \& Arain, M.B. 2014. Fluoride and arsenic exposure through water and grain crops in Nagarparkar, Pakistan. Chemosphere 100: 182-189.

Chaerun, S.K., Pangesti, N.P., Toyota, K. \& Whitman, W.B. 2011. Changes in microbial functional diversity and activity in paddy soils irrigated with industrial wastewaters in Bandung, West Java Province, Indonesia. Water Air and Soil Pollution 217: 491-502.

Chang, F.C., Ko, C.H., Tsai, M.J., Wang, Y.N. \& Chung, C.Y. 2014. Phytoremediation of heavy metal contaminated soil by Jatropha curcas L. Ecotoxicology 23(10): 1969-1978.

Constán-Nava, S., Bonet, A., Pastor, E. \& Lledó, M.J. 2010. Long-term control of the invasive tree Ailanthus altissima: Insights from Mediterranean protected forests. Forest Ecology and Management 260(6): 1058-1064.

Dadea, C., Russo, A., Tagliavini, M., Mimmo, T. \& Zerbe, S. 2017. Tree species as tools for biomonitoring and phytoremediation in urban environments: A review with special regard to heavy metals. Arboriculture and Urban Forestry 43(4): 155-167.

de Oliveira, L.M., da Silva, E.B., Gao, P., Vardanyan, L., Liu, Y. \& Ma, L.Q. 2018. Interactive effects of chromate and arsenate on their uptake and speciation in Pteris ensiformis. Plant Soil 422: 515-526.

de Oliveira, L.M., de Gress, J., Rathinasabapathi, B., Marchi, G., Chen, Y. \& Ma, L.Q. 2016. Sulfate and chromate increased each other's uptake and translocation in Ashyperaccumulator Pteris vittata L. Chemosphere 147: 36-43.

de Oliveira, L.M., Ma, L.Q., Santos, J.A., Guilherme, L.R. \& Less1, J.T. 2014. Effects of arsenate, chromate, and sulfate on arsenic and chromium uptake and translocation by arsenic hyperaccumulator Pteris vittata L. Environmental Pollution 184: 187192.

Hossain, M.A., Rahman, G.K.M.M., Rahman, M.M., Molla, A.H., Rahman, M.M. \& Uddin, M.K. 2015. Impact of industrial effluent on growth and yield of rice (Oryza sativa L.) in silty clay loam soil. Journal of Environmental Sciences 30: 231-240.

Huang, H., Yu, N., Wang, L., Gupta, D., He, Z., Wang, K., Yan, X., Li, T. \& Yang, X.E. 2011. The phytoremediation potential of bioenergy crop Ricinus communis for DDTs and cadmium co-contaminated soil. Bioresource Technology 102(23): 11034-11038.

Hussain, S., Akram, M., Abbas, G., Murtaza, B., Shahid, M., Shah, N.S., Bibi, I. \& Niazi, N.K. 2017. Arsenic tolerance and phytoremediation potential of Conocarpus erectus L. and Populus deltoides L. International Journal of Phytoremediation 19(11): 985-991.

Imtiazuddin, S., Mumtaz, M. \& Ahmed, T. 2014. Physicochemical analysis and heavy metals concentration in textile effluent in Karachi region of Pakistan. Global Journal of Environmental Science and Technology 2(5): 71-74.

Iqbal, M.A., Maqsood, Q., Ahmad, Z., Saleem, A., Afzal, S. \& Ahmad, B. 2015. A preliminary study on plant nutrients production as combined fertilizers, consumption patterns and future prospects for Pakistan. American-Eurasian Journal of Agriculture and Environmental Science 15(4): 588-594.

Ismail, A., Riaz, M., Akhtar, S., Ismail, T., Amir, M. \& Zafar-ulHye, M. 2014. Heavy metals in vegetables and respective soils irrigated by canal, municipal waste and tube well water. Food Additive Contaminants Part B 7(3): 213-219.

Issa, O.M., Défarge, C., Trichet, J., Valentin, C. \& Rajot, J.L. 2009. Microbiotic soil crusts in the Sahel of Western Niger and their influence on soil porosity and water dynamics. Catena 77(1): 48-55.

Kandziora-Ciupa, M., Ciepał, R., Nadgórska-Socha, A. \& Barczyk, G. 2016. Accumulation of heavy metals and antioxidant responses in Pinus sylvestris L. needles in polluted and non-polluted sites. Ecotoxicology 25(5): 970981.

Kumar, D., Tripathi, D.K., Liu, S., Singh, V.K., Sharma, S., Dubey, N.K., Prasad, S.M. \& Chauhan, D.K. 2017a. Pongamia pinnata (L.) Pierre tree seedlings offer a model species for arsenic phytoremediation. Plant Gene 11(Part B): 238246.

Kumar, D., Tripathi, D.K., Liu, S., Singh, V.K., Sharma, S., Dubey, N.K., Prasad, S.M. \& Chauhan, D.K. 2017b. Irrigation scheduling and fertilization improves production potential of jatropha (Jatropha curcas L.): A review. International Journal of Current Microbiology and Applied Sciences 6(5): 1703-1716.

Lessl, J.T., Guan, D.X., Sessa, E., Rathinasabapathi, B. \& Ma, L.Q. 2015. Transfer of arsenic and phosphorus from soils to the fronds and spores of arsenic hyperaccumulator Pteris vittata and three non-hyperaccumulators. Plant Soil 390: 49-60.

Lichtenthaler, H.K. 1987. Chlorophylls and carotenoids: Pigments of photosynthetic biomembranes. Methods in Enzymology 148: 350-382.

Luo, Z.B., He, J., Polle, A. \& Rennenberg, H. 2016. Heavy metal accumulation and signal transduction in herbaceous and woody plants: Paving the way for enhancing phytoremediation efficiency. Biotechnology Advances 34(6): 1131-1148.

Malik, R.N., Husain, S. \& Nazir, I. 2010. Heavy metal contamination and accumulation in soil and wild plant 
species from industrial area of Islamabad, Pakistan. Pakistan Journal of Botany 42(1): 291-301.

Manzoor, S., Mirza, S., Zubair, M., Nouman, W., Hussain, S., Mehmood, S., Sarwar, M., Ammar, A., Iqbal, M.F., Asim, A., Chattha, M.U., Chattha, M.B., Zafar, A. \& Abid, R. 2015. Estimating genetic potential of biofuel forest hardwoods to withstand metal toxicity in industrial effluent under dry tropical conditions. Genetics and Molecular Research 14(3): 9543-9554.

Mathews, S., Ma, L.Q., Rathinasabapathi, B., Natarajan, S. \& Saha, U.K. 2010. Arsenic transformation in the growth media and biomass of hyperaccumulator Pteris vittata $\mathrm{L}$. Bioresource Technology 101(21): 8024-8030.

Maurya, P.M. 2017. Physiochemical evaluation of woolen textile effluent impacted and un-impacted agricultural soil of Bikaner City, Rajasthan. International Journal of Multidisciplinary Allied Research Review and Practices 3(1): 1-8.

Mobar, S., Kaushik, P. \& Bhatnagar, P. 2015. Physiochemical comparison of textile effluent impacted and un-impacted agricultural soil of Jaipur city, India. International Journal of Recent Scientific Research 6(3): 3090-3093.

Nan, H., Jifang, Z., Dexin, D., Guangyue, L., Jie, Y., Xin, C. \& Jia, Y. 2013. Screening of native hyperaccumulators at the Huayuan River contaminated by heavy metals. Bioremediation Journal 17(1): 21-29.

Patel, R., Tajddin, K., Patel, A. \& Patel, B. 2015. Physicochemical analysis of textile effluent. International Journal of Research and Scientific Innovation 2(5): 33-37.

Rani, P., Kumar, A. \& Arya, R.C. 2017. Stabilization of tannery sludge amended soil using Ricinus communis, Brassica juncea and Nerium oleander. Journal of Soils and Sediments 17: $1449-1458$

Rasool, A., Xiao, T., Farooqi, A., Shafeeque, M., Liu, Y., Kamran, M.A., Katsoyiannis, I.A. \& Eqani, S.A.M.A.S 2017. Quality of tube well water intended for irrigation and human consumption with special emphasis on arsenic contamination at the area of Punjab, Pakistan. Environmental Geochemistry and Health 39(4): 847-863.

Rehim, A., Hussain, M., Hussain, S., Noreen, S., Doğan, H., Zia-Ul-Haq, M. \& Ahmad, S. 2016. Band-application of phosphorus with farm manure improves phosphorus use efficiency, productivity, and net returns of wheat on sandy clay loam soil. Turkish Journal of Agriculture and Forestry 40: 319-326.

Rekik, I., Chaabane, Z., Missaoui, A., Bouket, A.C., Luptakova, L., Elleuch, A. \& Belbahri, L. 2017. Effects of untreated and treated wastewater at the morphological, physiological and biochemical levels on seed germination and development of sorghum (Sorghum bicolor (L.) Moench), alfalfa (Medicago sativa L.) and fescue (Festuca arundinacea Schreb.). Journal of Hazardous Materials 326: 165-176.
Ronzan, M., Zanella, L., Fattorini, L., Della Rovere, F., Urgast, D., Cantamessa, S., Nigro, A., Barbieri, M., di Toppi, L.S. \& Berta, G. 2017. The morphogenic responses and phytochelatin complexes induced by arsenic in Pteris vittata change in the presence of cadmium. Environmental and Experimental Botany 133: 176-187.

Roohi, M., Riaz, M., Arif, M.S., Shahzad, S.M., Yasmeen, T., Riaz, M.A., Tahir, S. \& Mahmood, K. 2016. Varied effects of untreated textile wastewater onto soil carbon mineralization and associated biochemical properties of a dryland agricultural soil. Journal of Environmental Management 183(Part 3): 530-540.

Shah, F.U.R., Ahmad, N., Masood, K.R., Peralta-Videa, J.R., Zahid, D.M. \& Zubair, M. 2010. Response of Eucalyptus camaldulensis to irrigation with the Hudiara drain effluent. International Journal of Phytoremediation 12(4): 343357.

Shahid, M., Shamshad, S., Rafiq, M., Khalid, S., Bibi, I., Niazi, N.K., Dumat, C. \& Rashid, M.I. 2017. Chromium speciation, bioavailability, uptake, toxicity and detoxification in soilplant system: A review. Chemosphere 178: 513-533.

Shakoor, M., Niazi, N., Bibi, I., Rahman, M., Naidu, R., Dong, Z., Shahid, M. \& Arshad, M. 2015. Unraveling health risk and speciation of arsenic from groundwater in rural areas of Punjab, Pakistan. International Journal of Environmental Research and Public Health 12(10): 12371-12390.

Wang, W., Wu, Y., Akbar, S., Jia, X., He, Z. \& Tian, X. 2016. Effect of heavy metals combined stress on growth and metals accumulation of three Salix species with different cutting position. International Journal of Phytoremediation 18(8): 761-767.

Younas, U., Iqbal, S., Saleem, A., Iqbal, M., Nazir, A., Noureen, S., Mehmood, K. \& Nisar, N. 2017. Fertilizer industrial effluents: Physico-chemical characterization and water quality parameters evaluation. Acta Ecologica Sinica 37(4): 236-239.

Zare, A., Khoshgoftarmanesh, A., Malakouti, M., Bahrami, H. \& Chaney, R. 2018. Root uptake and shoot accumulation of cadmium by lettuce at various $\mathrm{Cd}$ : $\mathrm{Zn}$ ratios in nutrient solution. Ecotoxicology and Environmental Safety 148: 441-446.

Institute of Pure and Applied Biology

Bahauddin Zakariya University

Multan-60800

Pakistan

*Corresponding author; email: profrafia@gmail.com

Received: 20 February 2020

Accepted: 27 August 2020 